\title{
RELASI KEKUASAAN DALAM PEMBELAJARAN KIMIA PADA SMA RINTISAN SEKOLAH BERTARAF INTERNASIONAL DI BALI
}

\author{
I Gusti Lanang Wiratma \\ Universitas Pendidikan Ganesha, Jln. Udayana No. 11 Singaraja \\ e-mail: ramaglan99@gmail.com
}

\begin{abstract}
Power Relation in Chemistry Instruction at Pilot Project of International Senior High School in Bali. This study aimed at explaining the relation between the power and meanings behind the phenomenon occurred in the chemistry instruction in pilot project of international senior high school $(R S B I)$ in Bali. The study employed a qualitative method in particular phenomenological approach. The data were collected by using observation, interview, and document study. The instruments used were observation sheet, interview guideline, and check list. Subsequently, the collected data were analysed in a descriptive interpretative approach. The results show that the chemistry instruction has not yet conducted optimally due to lack of laboratory practices. This is resulted from the presence of hegemonic structure among the authority from the top to lower level and ultimately exert the power to students. As the consequence, the students do not obtain maximum learning experience as required by the curriculum and most likely they experience the unbalance of intelligence development as it was prioritized on cognitive rather than affective and psychomotor. This situation was worsened by the political imaging set up by the authorities to maintain their status quo that leads to co-modification culture in education.
\end{abstract}

Keywords: co-modification, education, laboratory, RSBI

\begin{abstract}
Abstrak: Relasi Kekuasaan dalam Pembelajaran Kimia pada SMA Rintisan Bertaraf Internasional di Bali. Penelitian ini bertujuan untuk menjelaskan relasi kekuasaan dan makna di balik fenomena yang terjadi pada pembelajaran kimia SMA Rintisan Sekolah Bertaraf Internasional (RSBI) di Provinsi Bali. Metode penelitian yang digunakan adalah metode kualitatif, dengan pendekatan fenomenologis. Cara pengambilan data dilakukan dengan observasi, wawancara, dan studi dokumen. Instrumen yang digunakan adalah pedoman observasi, pedoman wawancara, dan daftar chek (check list). Teknik analisis data yang digunakan adalah analisis diskriptif interpretatif. Hasil penelitian menunjukkan bahwa pembelajaran kimia belum dilakukan secara optimal karena sangat minim melakukan pembelajaran praktik di laboratorium. Hal ini disebabkan karena adanya hegemoni terstruktur yakni dari penguasa yang lebih tinggi ke penguasa yang lebih rendah, sampai pada siswa. Siswa tidak memeroleh pengalaman belajar yang maksimal seperti yang tertera di dalam kurikulum. Perkembangan kecerdasan siswa tidak seimbang, lebih mengutamakan ranah kognitif dari pada afektif dan psikomotor. Kondisi ini tercipta karena adanya kepentingan politik pencitraan untuk mempertahankan status quo yang cenderung mengarah pada budaya komodifikasi pendidikan.
\end{abstract}

Kata-kata Kunci: komodifikasi, laboratorium, pendidikan, RSBI

Reformasi di bidang pendidikan (khususnya mata pelajaran IPA) adalah sangat penting, terutama sejak diberlakukannya kurikulum berbasis kompetensi dengan penekanan pada pemahaman prinsip- prinsip alam serta mendorong peserta didik untuk bekerja dan bersikap ilmiah (Mulyasa, 2006). Kualitas pembelajaran IPA tidak cukup dengan mem- 
berikan informasi berupa teori, tetapi harus dibarengi dengan praktik laboratorium.

Menurut Whitten, dkk. (1988) ilmu kimia adalah cabang ilmu pengetahuan alam (sains) yang mempelajari materi yang meliputi sifat, struktur, perubahan, dan perubahan energi yang menyertai perubahan tersebut. Berdasarkan definisi tersebut, karakteristik ilmu kimia dapat dibagi dua, yaitu karakteristik makro dan karakteristik mikro. Secara makro, ilmu kimia terdiri atas fakta-fakta, konsep teoretis, hasil-hasil percobaan, dan manfaat ilmu kimia dalam kehidupan sehari-hari. Secara mikro ilmu kimia terdiri atas simbol, perjanjian, model dan perhitungan kimia. Jadi pembelajaran ilmu kimia sebagai bagian dari IPA tidak dapat lepas dari kegiatan praktikum yang bertujuan untuk verifikasi atau latihan penemuan.

Usaha untuk meningkatkan kualitas pembelajaran melalui peningkatan profesionalisme guru sudah banyak dilakukan namun, dalam kenyataannya proses pembelajaran belum menampakkan perubahan dan peningkatan yang berarti (Hasairin, 2008). Guru mengalami dilema dalam pengelolaan pembelajaran kimia, karena adanya tuntutan-tuntutan dari pihak pemerintah daerah melalui dinas pendidikan, agar siswa berhasil dalam menempuh ujian nasional (UN). Di samping tuntutan tersebut pimpinan di sekolah juga berharap agar siswa berhasil dalam mengikuti lomba-lomba akademik di tingkat regional, nasional, dan internasional. Sementara di sisi lain disadari bahwa keberhasilan dalam UN dengan tipe soal pilihan akan lebih mudah diraih apabila siswa dilatih menjawab soal. Pendapat guru kimia di lapangan menyatakan bahwa kontribusi pembelajaran praktikum sangat kecil terhadap keberhasilan peserta didik dalam UN. Kondisi seperti ini akhirnya guru lebih mengutamakan pembelajaran dengan latihan soal sehingga mengurangi porsi praktikum (Wiratma, 2011).

Dalam kondisi seperti tersebut di atas dapat dinyatakan bahwa telah terjadi hegemoni dari pihak penguasa yang memengaruhi guru dalam melaksanakan proses pembelajaran kimia di sekolah. Hegemoni tidak bisa dihindarkan dalam struktur kekuasaan, seperti hubungan sekolah dengan dinas pendidikan, atau kepala sekolah dengan guru, untuk menyukseskan program pendidikan. Namun demikian, hegemoni hendaknya dilaksanakan dalam kerangka pencapaian mutu proses pendidikan, bukan hasil kelulusan sebagai wujud pencitraan.
Hegemoni adalah bentuk ideologi yang di dalamnya ada nilai dan kepentingan kelompok hegemonik dialami oleh kelompok lainnya. Dominasi sebuah kelas sosial terhadap kelas lainnya, lewat keberhasilannya menanamkan pandangan hidup, relasi sosial, serta hubungan kemanusiaannya, sehingga diterima sebagai sesuatu yang dianggap benar oleh orang-orang yang sebetulnya tersubordinasi (Tilaar, 2003; Maliki, 2010).

Penelitian ini bertujuan untuk mengkajirelasi kekuasaan yang terjadi dan membedah makna yang ada di balik fenomena pembelajaran kimia di SMA RSBI di Bali. Manfaat penelitian adalah untuk mendapatkan kerangka konseptual pengelolaan pembelajaran kimia yang berkualitas, dan sebagai bahan pertimbangan untuk pengambilan kebijakan terhadap pelaksanaan pembelajaran kimia di sekolah.

\section{METODE}

Rancangan penelitian yang digunakan adalah penelitian kualitatif, yang bermaksud untuk memahami fenomena tentang apa yang dialami oleh subjek penelitian (Iskandar, 2008: 186; Moleong, 2007: 6). Teknik penentuan sampel dengan purposive sampling. Metode yang digunakan adalah observasi, wawancara, dan studi dokumen. Instrumen yang digunakan adalah pedoman observasi, pedoman wawancara, dan daftar chek (chek list). Teknik analisis data dilakukan dengan analisis diskriptif kualitatif interpretatif menurut versi Miles dan Huberman (1992:15-21). Pencarian data dengan mencermati perencanaan, pelaksanaan, penilaian, dan pengawasan pembelajaran kimia. Untuk memperoleh informasi mengenai perencanaan pembelajaran dilakukan dengan mewawancarai guru, kepala sekolah, dan pengawas, serta mencermati dokumen rencana pelaksanaan pembelajaran (RPP). Untuk memeroleh data mengenai pelaksanaan pembelajaran dilakukan dengan mewawancarai guru, siswa, kepala sekolah, dan pengawas, serta mengobservasi guru mengajar di kelas maupun di laboratorium. Untuk memeroleh informasi mengenai penilaian pembelajaran dilakukan dengan mewawancarai guru, siswa, serta mencermati dokumen RPP. Untuk mendapatkan informasi mengenai pengawasan dilakukan dengan mewawancarai pengawas, guru, kepala sekolah, dan dokumen hasil pengawasan. 
Standar yang digunakan untuk menginterpretasi pengelolaan pembelajaran kimia secara umum adalah Permendiknas No. 41 tahun 2007 tentang standar proses. Standar proses adalah standar nasional pendidikan yang berkaitan dengan pelaksanaan pembelajaran pada satuan pendidikan untuk mencapai kompetensi lulusan. Standar proses berisi kriteria minimal proses pembelajaran pada satuan pendidikan dasar dan menengah di seluruh wilayah hukum Negara Kesatuan Republik Indonesia. Standar proses meliputi perencanaan proses pembelajaran, pelaksanaan proses pembelajaran, penilaian hasil pembelajaran, dan pengawasan proses pembelajaran untuk terlaksananya proses pembelajaran yang efektif dan efisien (BSNP, 2007).

\section{HASIL DAN PEMBAHASAN}

Hasil yang diperoleh untuk aspek perencanaan pembelajaran berdasarkan wawancara ternyata proses penyusunan diawali dengan sosialisasi oleh kepala sekolah, kemudian dilakukan workshop, dilanjutkan dengan bimbingan teknis dan diskusi antar guru mata pelajaran, selanjutnya melakukan penyusunan perangkat pembelajaran. Di dalam proses penyusunan perangkat pembelajaran semua biaya dan fasilitas ditanggung oleh pihak sekolah, serta kepada guru yang telah menyusun perangkat pembelajaran diberikan insentif. Berdasarkan dokumen RPP ternyata perencanaan pembelajarannya jika di komparasi dengan standar proses pada aspek perencanaan ternyata sudah sesuai, dan bahkan ada hal yang lebih yaitu ada komponen penilaian karakter, ada yang berisi lembar kerja siswa (LKS) dan ada yang dibuat dalam dua bahasa yaitu bahasa Indonesia dan bahasa Inggris. Proses yang terstruktur yang dilakukan oleh pihak sekolah, agar menghasilkan perangkat pembelajaran yang lengkap karena adanya tuntutan diberlakukan manajemen ISO. Kelengkapan perangkat pembelajaran ini sebagai persyaratan penilaian administrasi dalam rangka mendapatkan sertifikat manajemen ISO, di samping sebagai kelengkapan administrasi guru. Kondisi ini yang menyebabkan pihak sekolah mengharuskan kepada guru untuk membuat perangkat pembelajaran yang lengkap sesuai dengan standar, dan diharapkan berkualitas. Tuntutan dari pimpinan di sekolah disebabkan karena tuntutan pihak pemerintah dalam hal ini melalui Diknas di daerah. Guru telah terhegemoni oleh kekuasaan, sehingga harus melakukan apa yang diharapkan oleh penguasa melalui pimpinan di sekolah.

Di dalam aspek pelaksanaan pembelajaran berdasarkan penyarian hasil wawancara bahwa guru ada yang mengajar beracuan pada RPP, dan ada guru yang mengajar tidak beracuan RPP. Guru yang mengajar tanpa beracuan RPP tetapi, berdasarkan buku teks yang dipakai pegangan belajar mengajar oleh guru dan murid. Metode pembelajaran lebih dominan dengan penjelasan konsep dan latihan soal, sebagai cara untuk meningkatkan aktivitas siswa. Sementara itu kegiatan praktikum sangat minim dan jauh dibawah dari tuntutan kurikulum. Sekolah melaksanakan program akselerasi sebagai pembelajaran tambahan pada sore hari, khusus membahas soal-soal mata pelajaran yang di UN kan, termasuk pelajaran kimia. Hal ini dilakukan karena guru berharap agar siswa yang di ajar berhasil dalam menghadapi UN, dan berhasil dalam mengikuti lomba-lomba akademik seperti olimpiade kimia. Keberhasilan siswa di dalam menempuh ujian nasional dan lomba akademik merupakan tuntutan kepala sekolah dengan maksud agar sekolah tetap dipercaya dan di idolakan oleh masyarakat. Berdasarkan hasil wawancara dengan beberapa guru mengatakan bahwa dalam setiap pertemuan kepala sekolah selalu menghimbau agar sekolah tetap mendapat kepercayaan masyarakat sebagai sekolah rintisan bertaraf internasional. Target utama yang disarankan adalah agar siswa selalu berhasil di dalam lomba-lomba ilmiah, berhasil di dalam ujian nasional. Keberhasilan siswa dalam ujian nasional merupakan harapan penguasa di daerah yang di wacanakan melalui kepala dinas pendidikan setempat. Hal yang senada juga dilakukan oleh pengawas sekolah, dalam kegiatan supervisi maupun pembinaan kepada guru-guru di sekolah.

Target keberhasilan dalam mengikuti lomba ilmiah, dan ujian nasional yang diharapkan kepada guru, tanpa disertai himbauan tentang proses pembelajaran yang dilakukan untuk mencapai target tersebut. Dengan kondisi itu guru memiliki kiat tertentu, dengan menganalisis sistem evaluasi dalam lomba dan ujian nasional yang ada maka, guru melaksanakan pembelajaran dengan metode diskusi dan latihan soal. Di samping dalam pembelajaran reguler, bahkan dalam pembelajaran tambahan yang diistilahkan program akselerasi juga di isi dengan latihan dan pembahasan soal-soal. 
Di dalam aspek penilaian pembelajaran guru melakukan dalam tiga domein yakni kognitif, afektif dan psikomotor. Penilaian kognitif cukup bervariasi, dilihat dari bentuk dan jenis penilaian. Guru melakukan penilaian dalam bentuk tes dan non tes. Penilaian dalam bentuk tes dilakukan dalam pembelajaran keseharian sebagai tes harian, tes tengah semester dan tes akhir semester. Penilaian non tes diberikan dalam bentuk tugas-tugas, dan pekerjaan rumah sebagai penilaian portofolio, yang dikerjakan dalam buku khusus kumpulan tugas siswa. Hasil penilaian digunakan sebagai pedoman untuk melaksanakan program remidi, perbaikan pembelajaran dan laporan hasil studi peserta didik. Sementara itu, penilaian afektif dan psikomotor sangat minim dilakukan karena guru belum memiliki pedoman penilaian yang baku. Di samping itu kegiatan yang terkait praktikum untuk penilaian psikomotor sangat minim. Dengan kondisi tersebut dapat dinyatakan bahwa pola berpikir guru telah terpaku pada kegiatan yang mendukung keberhasilan siswa pada UN, sehingga penilaian lebih mengutamakan ranah kognitif.

Untuk aspek pengawasan pembelajaran kimia dipilah menjadi dua yaitu pengawasan internal sekolah yang dilakukan oleh kepala sekolah dan pengawasan eksternal yang dilakukan oleh pengawas dari kantor dinas pendidikan. Pengawasan dari pihak internal lebih memberikan arti di mata guru, dibandingkan dengan pengawas eksternal. Pengawasan internal yang dilakukan oleh kepala sekolah atau pimpinan lain cukup intensif untuk seluruh guru, dengan melakukan pengawasan secara umum. Pemantauan, supervisi, evaluasi dan tindak lanjut dilakukan secara umum dan dilakukan pembinaan pada saat rapat guru, dan pertemuan-pertemuan lain. Pengawasan yang paling menonjol adalah evaluasi terhadap kelengkapan administrasi guru, catatan aktivitas, jurnal kegiatan, jurnal pembelajaran yang tercatat dengan format yang telah disediakan oleh bagian manajemen mutu. Motivasi dan pembinaan oleh kepala sekolah memberikan arti yang lebih bermakna bagi guru. Sementara itu, untuk pengawasan eksternal ternyata kondisinya bervariasi. Ada pengawas yang bidang keahliannya sesuai dengan bidang kimia dan ada pengawas yang bidang keahliannya pendidikan kewarganegaraan mengawasi guru kimia. Intensitas pengawasan sangat minim dan dalam pengawasan cenderung untuk memantau kelengkapan administrasi guru.
Intensitas pengawasan yang minim ke sekolah-sekolah karena seorang pengawas dalam bertugas mengawasi beberapa sekolah dan kadang memang mengawasi guru bidang studi yang berbeda dengan keahliannya. Dalam hal ini tampak ketidak seriusan dinas pendidikan dalam melakukan pengawasan sekaligus pembinaan kepada guru.

Mencermati pembelajaran dari aspek perencanaan, pelaksanaan, penilaian dan pengawasan, ternyata pengelolaan pembelajaran kimia belum dilakukan secara optimal dan cenderung parsial. Guru dalam melaksanakan pembelajaran mengebiri keprofesionalannya sebagai seorang pendidik. Hal ini terjadi karena guru mengalami hegemoni oleh kekuasaan. Dalam kondisi tersebut siswa terhegemoni oleh guru, dimana mereka harus menerima apa yang dilakukan guru walaupun kurikulum tidak diterapkan dengan optimal. Siswa tidak memperoleh pengalaman belajar/proses belajar yang maksimal terutama pengalaman praktikum, ada hak siswa yang terabaikan. Guru melakukan itu, karena ada tuntutan dari pihak pimpinan di sekolah agar siswa berhasil dalam menghadapi UN, dan lomba-lomba akademik. Guru berasumsi bahwa jika lebih banyak memberikan latihan soal maka lebih mudah menghadapi UN, dibandingkan dengan melakukan praktikum. Guru ingin menunjukkan keberhasilannya kepada pimpinan sekolah, karena harapan pimpinan adalah berhasil dalam UN dan lomba akademik. Keberhasilan siswa menghadapi UN, dan lomba akademik sebagai simbul keberhasilan sekolah yang ingin ditunjukkan kepada pemerintah melalui dinas pendidikan, dan kepada masyarakat bahwa sekolah yang dipimpin para siswanya unggul dan berprestasi. Kepala sekolah ingin mendapatkan pengakuan agar kepemimpinannya tidak digugat atau dimutasi, oleh penguasa. Penguasa juga ingin memertahankan status quo dan sebagai arena pencitraan dalam kepemimpinannya (Wiratma, 2013).

Hal senada diungkapkan Kerta Adhi (2013) menyatakan bahwa pengutamaan UN dilatarbelakangi oleh politik pendidikan dan kebijakan negara, yakni adanya ideologi dualisme kultural, permainan kuasa dan budaya citra, sosial budaya, yakni rasa takut dan malu, budaya paternalitis, pragmatis, konsumtif serta pengaruh global yang dicirikan oleh mata pelajaran sains dan teknologi, standarisasi, dan kompetisi (Kerta Adhi,2013). 
Pola berpikir guru yang senantiasa patuh dengan struktur di atas, terkait dengan permainan kekuasaan yang hegemonik. Titik awal konsep Antonio Gramsci tentang hegemoni dinyatakan bahwa, suatu kelas dan anggotanya menjalankan kekuasaan terhadap kelas-kelas di bawahnya dengan cara kekerasan dan persuasi. Di dalam permasalahan di atas sangat jelas terlihat bahwa siswa terhegemoni dan mengalami kekerasan simbolik dan persuasif oleh guru, kemudian guru terhegemoni oleh kepala sekolah, sementara itu, kepala sekolah terhegemoni oleh pihak pemerintah. Di sini telah terjadi hegemoni terstruktur yang tidak kasat mata, sebagai sebuah kesepakatan bersama. Kondisi ini mengakibatkan siswa telah kehilangan sebagian haknya untuk memeroleh pengalaman belajar yang lengkap, dalam rangka pengembangan potensi dirinya secara menyeluruh dan seimbang.

Hegemoni adalah bentuk ideologi yang di dalamnya ada nilai dan kepentingan kelompok hegemonik dialami oleh kelompok lainnya, sebagai telah menjadi milik mereka sendiri, dan telah disetujui. Dominasi sebuah kelas sosial terhadap kelas lainnya, lewat keberhasilannya menanamkan pandangan hidup, relasi sosial, serta hubungan kemanusiaannya, sehingga diterima sebagai sesuatu yang dianggap benar oleh orang-orang yang sebetulnya tersubordinasi. Pelaksanaan hegemoni dan keberhasilannya ditentukan oleh kesepakatan-kesepakatan. Kesepakatan terjadi melalui proses belajar atau dapat terjadi karena hubungan pendidikan (educational relationship). Hubungan pendidikan ini yang membentuk masyarakat madani yang di dalamnya terletak dasar dari kekuasaan. Di sinilah terletak peran lembaga-lembaga sosial ideologis, seperti hukum, pendidikan, media massa, agama dan yang lain sebagai arena pergulatan hegemoni. Dilihat dari segi ini, ternyata bahwa lembaga-lembaga sosial seperti sekolah dan lembaga-lembaga pendidikan lainnya tidak akan pernah netral, tetapi merupakan perekat dari hegemoni dalam masyarakat. Dengan kata lain, hegemoni terikat kepada kepentingan kelompok sosial yang berkuasa (Tilaar dan Nugroho, 2009).

Di balik keunggulan sekolah yang senantiasa dipertontonkan kehadapan publik dan kepada pemerintah tidak lepas dari kepentingan politik pencitraan. Pencitraan adalah proses, atau cara membentuk gambaran/kesan, sehingga pencitraan sekolah berarti proses atau cara yang dilakukan oleh se- kolah untuk membentuk gambaran atau kesan kepada masyarakat. Menurut Baudrillard (dalam Barker, 2008) kebudayaan pasca modern ditandai oleh arus besar simulasi dan citra yang menarik perhatian, suatu hiperrealitas di mana masyarakat dibanjiri dengan citra dan informasi. Bagi Jameson (dalam Barker, 2008) menyatakan pascamodern sebagai sesuatu yang ditandai oleh fragmentasi, instabilitas, dan disorientasi. Pascamodern adalah ekspresi dari sistem dunia multinasional atau kapitalisme dan merepresentasikan gaya kultural kapitalisme yang beroperasi pada ruang global baru. Budaya kapitalisme bergerak dengan cara memperluas komodifikasi kepada seluruh ranah kehidupan sosial dan kehidupan pribadi, dengan mentransformasikan yang nyata menjadi citra dan simulacrum. Citra sering kali mendahului narasi dan penglihatan, serta perasaan menjadi hal penting yang berarti tidak memperlihatkan yang sesungguhnya (Barker, 2008).

Jadi, memerhatikan keadaan yang terjadi di SMA RSBI, dimana telah terjadi ketidakseimbangan kegiatan pengelolaan pembelajaran antara aspek yang satu dengan yang lainnya. Kegiatan lebih mengutamakan pengembangan kecerdasan kognitif, kecerdasan intelektual semata dalam upaya mencapai keberhasilan menempuh ujian nasional dan lomba-lomba akademik. Ada beberapa kegiatan yang telah direncanakan dengan matang sebagai tuntutan kurikulum tidak dilakukan dengan baik. Dalam hal ini ada kecenderungan agar masyarakat memiliki kesan bahwa, sekolah tersebut unggul berprestasi. Pencitraan unggul dan berprestasi ini mengakibatkan orang tua siswa ingin agar anaknya dapat diterima di sekolah tersebut, walaupun dengan biaya yang lebih besar dari sekolah negeri lainnya. Pola berpikir pascamodern sudah memasuki dunia pendidikan dalam hal pencitraan, yang berpotensi sangat besar menjadi komodifikasi.

\section{SIMPULAN}

Pengelolaan pembelajaran kimia pada SMA RSBI di Provinsi Bali dengan arah penanaman kompetensi belum seimbang dan proporsional antara ranah kognitif, afektif dan psikomotorik, ternyata lebih mengutamakan pada ranah kognitif. Pengutamaan ranah kognitif dilakukan agar siswanya berhasil dalam menempuh UN dan lomba-lomba akademik. Hal ini dilakukan karena telah terjadi 
hegemoni struktural dari pihak yang memiliki struktur di atas kepada struktur yang di bawah atau kepada yang tersubordinasi. Pihak yang berkuasa memiliki kepentingan memertahankan posisinya melalui pencitraan. Citra sebagai sekolah unggulan di mata masyarakat dari keberhasilan dalam UN dan menjuarai lomba akademik akan mendongkrak popularitas sekolah. Masyarakat dengan sukarela mengeluarkan uangnya agar putra-putrinya dapat diterima di sekolah tersebut.

\section{DAFTAR RUJUKAN}

Badan Standar Nasional Pendidikan. 2007. Peraturan Menteri Pendidikan Nasional No. 41 Tahun 2007. Jakarta.

Barker, Chris. 2000. Cultural Studies Teori dan Praktik. Terjemahan oleh Nurhadi. 2008. Yogyakarta : Kreasi Wacana.

Hasairin, Ashar. 2008. Upaya Peningkatan Kualitas Pendidikan Indonesia Melalui Peningkatan Sumber daya Guru. Kumpulan Abstrak Konvensi Nasional Pendidikan Indonesia VI, 17-19 November.

Iskandar. 2008. Metodologi Penelitian Pendidikan dan Sosial (Kuantitatif dan Kualitatif). Jakarta: GP Press.

Kerta Adhi, Made. 2013. Pengutamaan Kebijakan Ujian Nasional dan Representasinya Pada Sistem Manajemen Pendidikan di Sekolah Menengah Atas. Disertasi tidak diterbitkan. Denpasar: UNUD.

Maliki, Zainuddin. 2010. Sosiologi Pendidikan. Yogyakarta: Gadjah Mada University Press.

Miles Matthew B. dan A. Micheael Huberman. Analisis Data Kualitatif. Terjemahan oleh Tjetjep Rohendi Rohidi. 2007. Jakarta: UI Press.
Berdasarkan kajian yang diuraikan di atas dapat disarankan agar pihak penguasa yang berpotensi melakukan hegemoni agar mengarahkan pihak sekolah dalam pengelolaan pembelajaran sesuai dengan tuntutan kurikulum. Kepada guru agar senantiasa meningkatkan profesionalitasnya sebagai pendidik, dan kepada pimpinan sekolah agar tidak menjadikan sekolah sebagai komuditas.

Moleong Lexy, J. 2007. Metodologi Penelitian Kualitatif. Bandung: Remaja Rosdakarya.

Mulyasa E. 2006. Kurikulum Berbasis Kompetensi. Bandung: PT Remaja Rosdakarya.

Tilaar, H.A.R. dan Nugroho, Riant. 2009. Kebijakan Pendidikan: Pengantar untuk Memahami Kebijakan Pendidikan sebagai Kebijakan Publik. Yogyakarta: PustakaPelajar.

Whitten, Gaileydan Davis. 1988. General Chemistry with Qualitative Analysis. $3^{\text {rd }}$ Ed. Philadelphia: Sauder College Publishing International Edition.

Wiratma, I G L. 2011. Profesionalisme Guru Kimia Pada SMA Negeri di Kabupaten Buleleng. Jurnal Pendidikan Kimia Indonesia,Vol.1, No.1: 59-66.

Wiratma, I G L. 2013. Pengelolaan Pembelajaran Kimia pada SMAN 1 Singaraja dan SMAN 1 Gianyar: Dekonstruksi Implementasi Standar Proses. Disertasi tidak diterbitkan. Denpasar: UNUD.

Wiratma, I G L. 2013. Hegemony of Chemistry Learning in Senior High School in Bali Province. E-Journal of Cultural Studies (Online), Vol.6 No. 2. (http://www.ojs.unud. ac.id, diakses 10 Agustus 2013). 